\title{
SOSOK 'MUSLIMAH' SEBAGAI SIMBOL KETELADANAN DALAM DUNIA PENDIDIKAN DI LPTK
}

\author{
Hj. Ida Rusdiana ${ }^{1}$ \\ 1. Pendidikan Bahasa Inggris STKIP-PGRI Banjarmasin \\ Idarusdiana68@gmail.com
}

\begin{abstract}
ABSTRAK
Muslimah Hafsari adalah seorang guru Sekolah Dasar dari Kepulauan Bangka Belitung, Sumatera. Sosok yang akrab dipanggil 'Bu Mus' ini merupakan sosok guru fenomenal yang membuat guru-guru Indonesia merasa sangat bangga menjadi seorang guru. Nasihat yang diberikan Bu Mus bagi guru-guru masa kini, yaitu: 1) Mengajarlah dengan hati agar yang kau ajarkan sampai ke hati, 2) Niatkan dari awal untuk selalu ikhlas dalam mengajar, 3) Kalaupun niatnya cari nafkah, sertakan tujuan untuk menabung amal di akhirat, 4) Kalau kita harus marah dengan anak-anak, marahlah tetap dengan hati sambil doakan agar kenakalan/perilakunya itu diampuni dan mendapat hidayah Allah SWT, 5) Dalam mengajar jangan hanya kejar target tuntasnya materi, tapi menghilangkan esensi. Harusnya utamakan esensi, baru materi. Dengan melakukan interpretasi terhadap nasihat itu, tulisan ini menyajikan gagasan untuk mengembangkan aspek kepribadian guru Indonesia dalam perspektif Islam melalui kegiatan pembelajaran yang bermakna. Adapun langkah-langkahnya dibagi dalam tiga tahap, yaitu: a. Sebelum Pembelajaran: 1) Memohon ampunan kepada orang tua dan minta untuk didoakan, 2) Meluruskan niat bahwa melaksanakan kegiatan pembelajaran adalah dalam rangka menjunjung perintah Allah SWT dan mengharap ridho-Nya, 3) Berwudhu, 4) Berdoa, 5) Berpakaian sesuai dengan tata tertib yang berlaku , 6) Berjalan menuju ruang kelas sambil bersholawat kepada Nabi Muhammad SAW, dan 7) Memasuki ruang kelas dengan kaki kanan sambil membaca Bismillahirahmanirahim; b. Saat Pembelajaran: 1) Mengucapkan dan membalas salam, 2) Berdoa bersama, 3) Membaca kitab suci (muslim: Al-Qur'an), 4) Menjaga perkataan yang baik dan menghindari perkataan yang tidak baik, 5) Mengingat kematian yang merupakan hal yang pasti terjadi, 6) Berzikir kepada Allah SWT, 7) Mengakhiri pembelajaran dengan mengucapkan istighfar, 8) Meminta maaf satu sama lain, 9) Mengucapkan dan membalas salam; dan c. Setelah Pembelajaran: 1) Menyediakan waktu belajar ilmu agama sesuai dengan keyakinan masing-masing, 2) Mencari guru agama yang berkualitas, 3) Merencanakan kegiatan belajar dengan berpedoman pada agama yang diyakini, dan 4) Mendoakan satu sama lain di setiap kesempatan.
\end{abstract}

Kata Kunci: Muslimah, Aspek Kepribadian Guru, Kegiatan Pembelajaran 


\section{PENDAHULUAN}

Mendengar nama 'Muslimah' disebut-sebut, pikiran kita dibawa menerawang untuk mengingat kembali sosok guru pada novel Laskar Pelangi yang ditulis Andrea Hirata pada tahun 2005. Novel yang ditulis berdasarkan kisah nyata dari Kepulauan Bangka Belitung Sumatera ini merupakan sebuah cerita yang sangat mengharukan tentang dunia pendidikan dengan tokoh-tokoh manusia sederhana, jujur, tulus, gigih, penuh dedikasi, ulet, sabar, takwa, dan tawakal kepada Tuhan yang Maha Kuasa: Allah SWT. Novel ini menampilkan sosok seorang guru yang akrab dipanggil 'Bu Mus'. Seorang pendidik yang berjuang tanpa pamrih dan mendedikasikan hidupnya untuk profesinya. Sosok guru yang tak pernah berhenti berjuang untuk mengajar murid-muridnya meskipun banyak dirundung kesusahan demi kesusahan. Sosok fenomenal yang membuat guru-guru Indonesia merasa sangat bangga menjadi seorang guru.

Berkat pengabdiannya yang tulus, ibu Muslimah Hafsari memperoleh penghargaan Satya Lencana Pendidikan yang diserahkan Presiden RI VI, Susilo Bambang Yudhoyono, dalam puncak acara Hari Guru Nasional dan Peringatan HUT PGRI ke-63 di Tennis Indoor, Senayan, Jakarta. Adapun wejangan atau nasihat yang pernah disampaikan beliau bagi guru-guru masa kini sebagaimana yang dikutip dari Sangpencerah.id, yaitu: 1) Mengajarlah dengan hati agar yang kau ajarkan sampai ke hati, 2) Niatkan dari awal untuk selalu ikhlas dalam mengajar, 3) Kalaupun niatnya cari nafkah, sertakan tujuan untuk menabung amal di akhirat, 4) Kalau kita harus marah dengan anak-anak, marahlah tetap dengan hati sambil doakan agar kenakalan/perilakunya itu diampuni dan mendapat hidayah Allah SWT, 5) Dalam mengajar jangan hanya kejar target tuntasnya materi, tapi menghilangkan esensi. Harusnya utamakan esensi, baru materi.

Saat ini, di tengah perbaikan kualitas dan kesejahteraan guru akibat 'kesaktian Undang-Undang Nomor 14 Tahun 2005 Tentang Guru dan Dosen', adakah hal itu akan menjadi jaminan pula bagi peningkatan etos kerja dan profesionalitas para guru dan dosen di Indonesia? Akankah mereka menjadi lebih berkompeten, lebih terampil, lebih rajin, lebih disiplin, lebih bersemangat, dan lebih bergairah dalam melaksanakan tugas-tugas dan tanggung jawab profesinya sebagai seorang pendidik? Apakah sosok 'Muslimah' masih melekat pada pribadi-pribadi guru dan dosen Indonesia? Akankah sosok ini kian hari kian jauh dari sosok guru dan dosen Indonesia?

Tentu saja mimpi ini menjadi harapan besar kita semua mengingat guru dan dosen (selanjutnya disebut guru) memang menempati posisi sentral karena peran dan fungsinya yang sangat strategis dalam rangka mencerdaskan kehidupan bangsa. Guru memiliki tanggung jawab besar dalam upaya mewujudkan tujuan pendidikan nasional. Sehebat apapun sebuah visi-misi, kurikulum, dan kekuatan finansial, sepanjang guru pasif dan stagnan, maka kualitas pendidikan akan merosot tajam. Sebaliknya, selemah apapun sebuah visi-misi, kurikulum dan kekuatan finansial, jika guru progresif, produktif, dan inovatif, maka kualitas pendidikan akan semakin meningkat. Apalagi jika sistem yang baik ditunjang dengan kualitas guru yang inovatif maka perkembangan dunia pendidikan Indonesia akan maju pesat. 
Fakta yang ada menunjukkan, banyak guru di negeri ini belum sesuai dengan harapan di atas. Mereka belum mencerminkan sebuah sosok guru ideal yang siap mendidik siswa dan mahasiswanya (selanjutnya disebut siswa) dengan profesionalisme dan optimisme, kapasitas intelektual yang rendah, kedisiplinan yang lemah, semangat belajar yang hampir hilang, integritas moral yang sering menyeleweng, dan dedikasi sosial yang kurang (Asmani, 2013:7).

Pengalaman penulis menjadi murid sangat membekas dalam jiwa ini, betapa guru yang ideal dan inovatif mampu menyulut api idealisme. Melihat wajah mereka dan mendengarkan penjelasannya di dalam kelas rasanya ada kepuasan batin, pencerahan jiwa, dan pendorong cita-cita tinggi di masa depan. Melalui ucapan mereka tidak ada kata mundur, menyerah, dan putus asa, yang ada adalah tekad, semangat, dan keyakinan kuat akan datangnya masa depan yang cerah; masa depan yang mampu mendatangkan kemanfaatan sebesar-besarnya bagi agama, masyarakat, bangsa dan negara.

Guru seperti inilah yang dapat melahirkan generasi yang cerdas dan potensial di masa depan. Guru memegang peranan sentral dalam mengarahkan pikiran siswa untuk melihat dunia yang berkembang dengan cepat dan dinamis, apalagi di era revolusi digital saat ini. Era revolusi digital adalah suatu jaman dimana perkembangan teknologi informasi sangat cepat dalam segala bidang termasuk bidang pendidikan. Tanggung jawab guru dan dosen tidak hanya membuka jendela dunia tetapi sekaligus menyeleksi, memfilter, dan memberikan informasi terbaik bagi siswa-siwa mereka.

Guru yang berkualitas lahir dari sebuah proses yang berkualitas. Proses yang berkualitas terdapat pada lembaga-lembaga pendidikan yang berkualitas. Salah satu lembaga yang berperan besar dalam menghasilkan guru-guru yang berkualitas adalah Lembaga Pendidikan Tenaga Kependidikan (LPTK). Agar lulusan LPTK mampu menjadi agen perubahan dalam sistem pendidikan, terlebih dahulu dosen yang 'mencetak' mereka sudah menjadi 'agen perubahan'. Agen perubahan yang dimaksud dalam tulisan ini ada dua makna: 1) agen perubahan adalah sosok atau pribadi yang selalu berupaya optimal menyertakan Tuhan Yang Maha Esa dalam setiap perkataan dan tindakan yang dilakukan dalam mengelola kegiatan pembelajaran; dan 2) agen perubahan di era revolusi digital yang progresif dan selektif.

Agen perubahan sebagai sosok pribadi yang selalu berupaya menyertakan Tuhan Yang Maha Esa maknanya adalah guru selalu melakukan instrospeksi diri terhadap apa yang telah, sedang, dan akan dilakukan dalam mengelola kegiatan pembelajaran berdasarkan prinsip agama dan keyakinan masing-masing. Contohnya bersikap jujur, disiplin, dan bertanggung jawab. Sedangkan, agen perubahan di era revolusi digital bermakna guru menyadari bahwa teknologi informasi hanyalah media dalam pembelajaran dan memiliki dampak positif dan negatif terhadap perkembangan pribadi para siswa. Contohnya menyaring setiap informasi yang masuk, bijaksana dalam mengelola informasi, dan kritis dalam menghadapi globalisasi.

Tulisan ini menyajikan gagasan untuk mengembangkan aspek kepribadian guru melalui kegiatan pembelajaran untuk mencapai hasil pembelajaran yang optimal. Secara berturut-turut dalam tulisan ini dibahas: 1) bagaimana sistem pendidikan di era 
revolusi digital?; 2) bagaimana lulusan LPTK mampu menjadi agen perubahan?; 3) bagaimana implementasinya dalam kegiatan belajar mengajar?. Tulisan ini penting untuk menjadi bahan diskusi mengingat sosok guru diharapkan mampu menjadi teladan bagi peserta didik. Mereka adalah sosok yang diharapkan dapat membawa perubahan untuk masa depan pendidikan Indonesia yang lebih baik.

\section{METODE PENULISAN}

Makalah ini menggunakan pendekatan kualitatif yaitu mencoba memahami secara mendalam fenomena yang ada, kemudian memberi arti dan makna serta mencari sebab akibat dan pemecahannya dengan menggunakan analisis yang logis. Metode yang diterapkan berupa metode kepustakaan, yaitu dengan cara mempelajari buku-buku atau literature yang ada hubungannya dengan permasalahan yang diteliti. Teknik analisa data secara deskriptif interpretative yaitu dengan memaparkan data secara keseluruhan terlebih dahulu, setelah terkumpul dan terjaring kemudian peneliti menginterpretasikannya.

\section{PEMBAHASAN}

\section{Sistem Pendidikan di Era Revolusi Digital}

Perkembangan Teknologi Informasi dan Komunikasi (TIK) telah memberikan pengaruh besar terhadap dunia pendidikan, khususnya dalam proses pembelajaran. Menurut Rosenberg dalam Suyanto dan Jihad (2013:176), ada lima pergeseran dalam proses pembelajaran seiring dengan berkembangnya penggunaan TIK, yaitu:

a. Dari pelatihan ke penampilan;

b. Dari ruang kelas ke mana pun dan kapan pun;

c. Dari kelas ke online;

d. Dari fasilitas fisik ke fasilitas jaringan kerja;

e. Dari waktu siklus ke waktu nyata.

Komunikasi sebagai media pendidikan dilakukan dengan menggunakan berbagai sarana seperti telepon, komputer, internet, e-mail, dan layanan pesan singkat. Interaksi antara guru dan siswa tidak hanya dilakukan melalui hubungan tatap muka, tetapi juga dengan menggunakan media-media tersebut. Guru dapat memeberikan layanan tanpa harus berhadapan langsung dengan siswa. Demikian pula siswa dapat memperoleh informasi dalam lingkup yang luas dari berbagai sumber melalui cyber space atau ruang maya dengan menggunakan internet.

Internet merupakan salah satu instrument dalam era globalisasi yang telah menjadikan dunia ini transparan dan terhubung dengan sangat mudah dan cepat tanpa mengenal batas-batas kewilayahan atau kebangsaan. Melalui internet, setiap orang dapat mengakses dunia global untuk memperoleh informasi dalam berbagai bidang. Pada gilirannya, internet akan memberikan pengaruh pada keseluruhan perilaku orang yang menggunakannya. 
TIK memberikan wajah baru dalam dunia pembelajaran kontemporer- berbeda dengan proses pembelajaran tradisional yang membutuhkan interaksi tatap muka antara guru dan siswa, baik di kelas maupun di luar kelas. Di masa-masa mendatang, arus informasi akan makin meningkat melalui jaringan internet yang bersifat global di seluruh dunia dan menuntut siapa pun, apalagi guru untuk beradaptasi dengan kecenderungan itu jika tidak mau ketinggalan zaman. Dengan kondisi demikian, pendidikan khususnya proses pembelajaran cepat atau lambat tidak dapat terlepas dari keberadaan komputer dan internet sebagai alat bantu utama.

Perkembangan mutakhir dalam dunia pendidikan diikuti dengan munculnya fenomea yang disebut sebagai "cyber teaching" atau pengajaran maya (Suyanto dan Jihad, 2013:179), yaitu proses pengajaran yang dilakukan menggunakan internet. Istilah lain yang makin popular saat ini ialah e-learning, yaitu media pembelajaran dengan menggunakan media teknologi komunikasi dan informasi khususnya internet. Ruang kelas di masa yang akan datang disebut sebagai "cyber classroom" atau "ruang kelas maya" sebagai tempat anak-anak melakukan aktivitas pembelajaran secara individual dan kelompok dengan pola belajar yang disebut "interactive learning" atau pembelajaran interaktif melalui computer yang tersambung di internet. Para siswa berhadapan dengan komputer dan melakukan aktivitas pembelajaran secara interaktif melalui jaringan internet untuk memperoleh materi belajar dari berbagai sumber belajar.

Penggunaan E-Learning membuat siswa dapat melakukan kegiatan belajar sesuai dengan kondisi kemampuan individualnya sehingga mereka yang lambat atau cepat dalam menerima pembelajaran akan memperoleh pelayanan pembelajaran yang sesuai dengan kapasitas dirinya. Kurikulum dikembangkan sedemikian rupa dalam bentuk yang lebih fleksibel sesuai dengan kondisi lingkungan dan kondisi siswa sehingga memberikan peluang untuk terjadinya proses pembelajaran yang maju dan berkelanjutan baik dalam dimensi ruang, waktu, maupun materi. Dalam situasi seperti ini, guru bertindak sebagai fasilitator pembelajaran, sementara siswa berperan aktif dalam proses pembelajaran, sehingga terjadi komunikasi pikiran antara guru dan siswa melalui perantaraan teknologi. Meskipun TIK dalam bentuk komputer dan internet telah terbukti banyak menunjang proses pembelajaran siswa secara lebih efektif dan produktif, namun di sisi lain internet sebagai modalitas pembelajaran juga masih banyak kelemahan dan kekurangan (Suyanto dan Jihad, 2013:180), mislanya:

a. Siswa lebih asyik dengan internetnya itu sendiri daripada materi yang dipelajari;

b. Proses pembelajaran menjadi individual sehingga siswa tidak ememiliki kecerdasan sosial;

c. Pengetahuan dari internet tidak memberikan jaminan ketepatan sehingga berbahaya bagi anak yang kurang kritis terhadap apa yang ia peroleh;

d. Penggunaan internet yang kurang proporsional dapat merugikan peningkatan kemampuan siswa Sekolah Dasar yang bersifat manual seperti menulis tangan, menggambar, dan berhitung.

Dalam menyikapi hal ini guru perlu memiliki kemampuan dalam mengelola kegiatan pembelajaran secara proporsional. Selain itu, perlu adanya kerja sama yang 
baik antara guru dan orang tua. Hal ini senada dengan pernyataan Donyei dalam Patil (2008) yang menyatakan bahwa pembelajaran akan mencapai hasil optimal jika suasana kelas itu rileks, menyenangkan, dan nyaman. Orang tua dapat membantu guru dengan cara membimbing anak belajar. Hal ini dilakukan agar mereka tidak terjerumus pada pemanfaatan internet dengan memasuki situs-situs yang terlarang baginya, seperti situs pornografi dan kekerasan.

Langkah selanjutnya yang harus diberikan guru kepada siswa adalah memberikan prinsip progresif dan selektif. Progresif berarti strategi menghadapi globalisasi ini tidak hanya defensive (mempertahankan diri dari serangan luar), tapi juga progresif (maju ke depan melakukan kemajuan-kemajuan secara cepat dan bertahap). Artinya, anak didik didorong untuk menjadi seorang pemain dan subjek dari globalisasi, bukan terus menerus menjadi penonton, sasaran, dan objek globalisasi yang selalu dipermainkan, dihancurkan, dan direkayasa masa depannya. Dalam kaitannya dengan aspek kepribadian calon lulusan LPTK, progresif berarti calon lulusan LPTK didorong untuk berupaya secara terus-menerus menjadi pribadi yang berkualitas dengan cara menghayati dan mengamalkan ajaran agama yang dianutnya.

Selain itu, strategi ke depan harus mengedepankan prinsip selektif, pandai memilih mana yang baik dan mana yang buruk, mana yang menjadi prioritas, mana yang bernilai strategis, dan mana yang bernilai jangka panjang. Prinsip progresif dan selektif akan membawa anak bangsa ini meraih puncak prestasi yang diidamidamkan. Guru harus berperan besar menjadi pembangkit semangat anak didik untuk menerapkan prinsip progresif dan selektif ini dalam mengejar masa depannya. Namun, jangan sampai melupakan prinsip defensif, dalam arti mempunyai pertahanan yang kuat ketika diserang dengan godaan-godaan yang memikat dan melenakan.

\section{Lulusan LPTK Sebagai Agen Perubahan}

Ada dua prinsip yang harus diajarkan pada agen perubahan. Pertama adalah prinsip moralitas; kedua adalah prinsip efisiensi. Hubungan efisiensi dan moralitas yang saling mempengaruhi pada berbagai institusi, terutama institusi pendidikan yang kita sebut sekolah, terus menggugah rasa ingin tahu. Di permukaan, moralitas maupun efiesiensi sangat baik; moralitas menunjukkan kejujuran, kebaikan, dan perilaku yang baik dan lain-lain, dan efisiensi memperlihatkan prestasi dan produksi maksimum dengan pengeluaran usaha, uang, dan waktu minimum. Idealnya, sekolah, pemerintahan, tempat kerja, dan bahkan keluarga kita bermoral dan memiliki efisiensi dengan caranya sendiri (Roosevelt dalam Case dkk. 2009).

Pernyataan Roosevelt selaras dengan pendapat Harmer (2007:56) yang menyebutkan bahwa guru adalah seseorang yang selalu berusaha mengasah kemampuan intelegensinya dari seluruh aspek spiritual, yahudi, emosional, fisik dan intelektual. Selanjutnya, Golberg (2003:224) menyatakan bahwa guru yang hebat adalah seseorang yang selalu jujur dalam bersikap dan penuh perhatian dengan peserta didik. Pernyataan Golberg ini didukung oleh pendapat Strong (2002:14) yang menyatakan bahwa seorang guru yang baik adalah guru yang selalu peduli, mendengarkan dan memahami para siswa. 
Di Indonesia, prinsip-prinsip moralitas yang berhubungan dengan dunia pendidikan itu telah diatur dalam sistem perundang-undangan sebagai berikut:

a) Tujuan Pendidikan Nasional dalam UUD 1945 (versi Amandemen)

1. Pasal 31, ayat 3 menyebutkan, "Pemerintah mengusahakan dan menyelenggarakan satu sistem pendidikan nasional, yang meningkatkan keimanan dan ketakwaan serta akhlak mulia dalam rangka mencerdaskan kehidupan bangsa yang diatur dengan undang-undang."

2. Pasal 31, ayat 5 menyebutkan, "Pemerintah memajukan ilmu pengetahuan dan teknologi dengan menunjang tinggi nilai-nilai agama dan persatuan bangsa untuk kemajuan peradaban serta kesejahteraan umat manusia."

b) Tujuan Pendidikan Nasional dalam Undang-Undang No. 20, Tahun 2003

Jabaran UUD 1945 tentang pendidikan dutuangkan dalam Undang-Undang No. 20, Tahun 2003. Pasal 3 menyebutkan, "Pendidikan nasional berfungsi mengembangkan kemampuan dan membentuk watak serta peradaban bangsa yang bermartabat dalam rangka mencerdaskan kehidupan bangsa, bertujuan untuk berkembangnya potensi peserta didik agar menjadi manusia yang beriman dan bertakwa kepada Tuhan yang Maha Esa, berakhlak mulia, sehat, berilmu, cakap, kreatif, mandiri, dan menjadi warga Negara yang demokratis serta bertanggung jawab."

c) Kompetensi Guru dalam Undang-Undang No. 14 Tahun 2005 Pasal 10 Ayat 1

Kompetensi guru sebagaimana dimaksud dalam Pasal 8 meliputi kompetensi pedagogik, kompetensi kepribadian, kompetensi sosial, dan kompetensi profesional yang diperoleh melalui pendidikan profesi. Adapun prinsip moralitas yang harus dimiliki oleh guru, dosen, maupun lulusan LPTK sebagai agen perubahan, digambarkan dengan jelas melalui kompetensi kepribadian.

Kompetensi Kepribadian adalah kemampuan personal yang mencerminkan kepribadian yang mantap, stabil, dewasa, arif dan berwibawa, menjadi teladan bagi peserta didik, dan berakhlak mulia. Sub kompetensi dalam kompetensi kepribadian meliputi :

1. Kepribadian yang mantap dan stabil meliputi bertindak sesuai dengan norma sosial, bangga menjadi guru, dan memiliki konsistensi dalam bertindak sesuai dengan norma.

2. Kepribadian yang dewasa yaitu menampilkan kemandirian dalam bertindak sebagai pendidik dan memiliki etod kerja sebagai guru.

3. Kepribadian yang arif adalah menampilkan tindakan yang didasarkan pada kemamfaatan peserta didik, sekolah dan masyarakat dan menunjukkan keterbukaan dalam berpikir dan bertindak.

4. Kepribadian yang berwibawa meliputi memiliki perilaku yang berpengaruh positif terhadappeserta didik dan memiliki perilaku yangh disegani. 
5. Berakhlak mulia dan dapat menjadi teladan meliputibertindak sesuai dengan norma religius (imtaq, jujur, ikhlas, suka menolong) dan memiliki perilaku yang diteladani peserta didik.

Selain peraturan perundang-undangan di atas, terdapat pula Peratuan Presiden Republik Indonesia No. 8 Tahun 2012 Tentang Kerangka Kualifikasi Nasional Indonesia yang mendeskripsikan bahwa seorang lulusan harus:

a. Beriman dan bertakwa kepada Tuhan Yang Maha Esa.

b. Memiliki moral, etika dan kepribadian yang baik di dalam menyelesaikan tugasnya.

c. Berperan sebagai warga negara yang bangga dan cinta tanah air serta Deskripsi mendukung perdamaian dunia.

d. Mampu bekerja sama dan memiliki kepekaan sosial dan kepedulian yang tinggi terhadap masyarakat dan lingkungannya.

e. Menghargai keanekaragaman budaya, pandangan, kepercayaan, dan agama serta pendapat/temuan original orang lain.

f. Menjunjung tinggi penegakan hukum serta memiliki semangat untuk mendahulukan kepentingan bangsa serta masyarakat luas.

Guru yang professional tentu saja bukan guru yang bekerja sekedar menanggalkan kewajiban-kewajibannya atau cuma memperhatikan kelengkapan administratif semata, apalagi yang hanya berorientasi pada aspek materil saja. Jamaludin (2010:14) berpendapat bahwa Ketika profesi guru sudah menjadi pilihan, maka sebagai konsekuensinya setiap orang yang merasa dirinya telah menjadi seorang guru sudah seyogyanya berusaha semaksimal mungkin untuk melaksanakan tugas-tugasnya secara profesional.

\section{Implementasi dalam Kegiatan Belajar Mengajar}

Berdasarkan paparan di atas, guru hendaknya selalu menghadirkan Tuhan Yang Maha Esa dalam mengelola pembelajaran yang dilaksanakan. Sebagai seorang muslim, penulis tidak dapat menghindari contoh-contoh yang dipaparkan dalam implementasinya berhubungan dengan hal-hal yang idealnya dilakukan oleh seorang muslim.

\section{Sebelum Pembelajaran}

a. Memohon ampunan kepada orang tua dan minta untuk didoakan

Pencapaian maksimal dalam kegiatan pembelajaran tentunya tidak luput dari kekuatan doa. Adapun doa yang paling besar kekuatannya terdapat pada doa orang tua. Oleh karena itulah, sebelum pembelajaran seorang guru disarankan untuk meminta ampunan dan doa kepada orang tua.

b. Meluruskan niat bahwa melaksanakan kegiatan pembelajaran adalah dalam rangka menjunjung perintah Allah SWT dan mengharap ridho-Nya 
Dalam Islam, hikmah penciptaan manusia adalah untuk beribadah kepada Allah SWT. Semua kegiatan yang dilakukan di dunia di landaskan pada niat bahwa hal itu dilakukan untuk mencari ridho Allah SWT. Oleh karena itulah, seorang guru perlu meluruskan niat sebelum memulai pelajaran.

c. Berwudhu

Ada banyak manfaat berwudhu, diantaranya adalah merenggangkan syarafsyarat otot yang kaku, menyegarkan pikiran, dan mencerahkan muka. Wudhu yang dilakukan sebelum mengajar akan memeberikan efek positif terhadap kesehatan psikis guru, sehingga besar kemungkinan bahwa guru yang berwudhu dapat menghadapi tantangan yang akan terjadi di kelas dengan hati yang lapang dan pikiran yang tenang.

d. Berdoa

Doa adalah senjata orang mukmin dalam segala keadaan dan suasana, tatkala bahagia dia harus bersyukur dengan banyak memuji kepada Allah SWT. Dalam keadaan berduka seorang hamba harus mohon kekuatan dan keteguhan hati agar Allah SWT menjadikannya kuat dan tegar. Begitulah doa dengan izin Allah SWT, akan selalu memotivasi untuk optimis dan semangat dalam mengajar.

e. Berpakaian sesuai dengan tata tertib yang berlaku

Seorang guru harus senantiasa berpenampilan bersih dan rapi sebagai cerminan dari profesionalitas. Selain itu, guru dan dosen juga merupakan teladan bagi peserta didik sehingga mereka harus berpakaian sesuai dengan norma dan tata tertib yang berlaku.

f. Berjalan menuju ruang kelas sambil bersholawat kepada Nabi Muhammad SAW

Nabi Muhammmad SAW merupakan sosok yang sangat dimuliakan dalam ajaran Islam. Beliau adalah sosok teladan bagi umat muslim karena sikap nya yang terpuji. Bershalawat kepada Nabi berarti memuji beliau dan merupakan sebuah perwujudan akan kecintaan terhadap sosok mulia tersebut. Dengan senantiasa mencintai sosok teladan tersebut tentunya seorang pendidik akan selalu termotivasi untuk mengikuti sikap-sikap terpuji dari beliau yang pada akhirnya dapat diterapkan dalam pembelajaran.

g. Memasuki ruang kelas dengan kaki kanan sambil membaca Bismillahirahmanirahim

Seseorang muslim memiliki keyakinan bahwa dia tidak mungkin dapat mengajar dan belajar dengan baik kalau tidak dengan pertolongan dari Allah SWT. Maknanya adalah hanya Allah SWT yang Maha Alim dan Maha Bijaksana yang bisa mengubah guru dan siswa biasa menjadi orang-orang luar biasa.

\section{Saat Pembelajaran}

a. Mengucapkan dan membalas salam

Melalui ucapan salam ini dosen menyatakan bahwa dia hanyalah seorang manusia biasa yang lemah dan dia sangat berharap doa dari pada siswanya karena ucapan itu wajib dibalas. Ketika ada dua puluh sampai tiga puluh orang siswa yang 
mendoakan dirinya, maka seorang guru meyakini bahwa minimal doa dari salah seorang di antara mereka dikabulkan oleh Allah SWT.

b. Berdoa bersama

Di dalam setiap pembelajaran pasti akan terdapat tantangan maupun masalah yang dihadapi guru maupun siswa. Oleh karena itu, dengan berdoa bersama ketika sedang belajar maka diharapkan pembelajaran tersebut dapat memberikan hasil yang memuaskan: guru dapat menjelaskan pelajaran dengan baik sehingga siswa dapat memahami pelajaran dengan baik.

c. Membaca kitab suci (muslim: Al-Qur'an)

Membaca Al-Qur'an dapat menenangkan pikiran dan batin serta membuat hati tenang sehingga guru dan siswa yang membaca Al-Qur'an dapat menghadapi segala permasalahan dalam pembelajaran dengan pikiran dan hati yang tenang.

d. Menjaga perkataan yang baik dan menghindari perkataan yang tidak baik.

Dalam pembelajaran sangat penting menjaga suasana kelas agar tetap nyaman dan kondusif. Salah satu caranya adalah dengan berkata-kata yang baik dan menghindari kata-kata yang tidak baik, terutama bagi seorang guru. Selain itu, pendidikan bukan hanya tentang nilai tetapi, bagaimana siswa nanti nya dapat menggunakan ilmu mereka dalam kehidupan bermasyarakat. Itulah pentingnya pembiasaan untuk selalu bertutur kata yang baik selama pembelajaran karena di kehidupan bermasyarakat semua orang harus bertutur kata yang sesuai dengan norma masyarakat.

e. Mengingat kematian yang merupakan hal yang pasti terjadi.

Kematian merupakan pemisah antara kehidupan dunia dan kehidupan akhirat. Hal ini juga berarti bahwa kematian merupakan pemisah antara waktu beramal dengan waktu pembalasan amal di akhirat kelak. Guru sebagai pendidik yang selalu mengingat kematian akan sadar bahwa segala sesuatu yang ia lakukan merupakan bekal yang sudah ia persiapkan untuk dihitung di akhirat kelak. Oleh karena itu, mereka akan menjalani profesinya dengan ikhlas dan tanpa pamrih serta tidak mengharapkan balasan dari peserta didiknya karena mereka yakin Allah SWT akan membalas amal yang sudah mereka kerjakan dengan balasan yang adil.

\section{f. Berzikir kepada Allah SWT.}

Setiap umat beragama pasti meyakini bahwa Tuhan adalah penentu segalanya dalam kehidupan, termasuk dalam proses pembelajaran yang melibatkan guru dan siswa. Bagi umat muslim, semua kegiatan dilandaskan pada usaha dan ikhtiar serta tawakal kepada Allah SWT. Allah SWT yang akan dapat menolong apabila terjadi sesuatu hal yang tidak diharapkan terjadi di dalam kelas. Oleh karena itu, guru maupun siswa hendaknya selalu mengingat Allah SWT dalam setiap proses pembelajaran yang dilalui. 
g. Mengakhiri pembelajaran dengan mengucapkan istighfar.

Dalam pandangan umat islam, keutamaan istigfar kepada Allah SWT adalah menggugurkan dosa seperti yang tersirat dalam hadist tersebut. Guru dan siswa adalah manusia yang tentunya tidak luput dari kesalahan. Melalui istighfar diharapkan pembelajaran dapat diakhiri dengan evaluasi terhadap diri sendiri, seperti kesalahan apa yang telah dibuat, kekurangan apa yang perlu diperbaiki, sikap seperti apa yang harus di evaluasi dan sebagainya.

h. Meminta maaf satu sama lain.

Kesalahan, kekhilafan, dan salah paham antar guru dan siswa senantiasa terjadi karena semuanya merupakan manusia biasa yang tidak luput dari ketiga hal tersebut. Oleh karena itu, saling memaafkan satu sama lain sangatlah penting agar pikiran dapat menjadi jernih dan positif untuk menghadapi pembelajaran yang akan datang. Dengan saling meminta maaf satu sama lain, orang yang memiliki kesalahan dapat belajar dari kesalahannya dan orang yang memaafkan tidak terbebani pikirannya dan mendapat derajat yang mulia di sisi Tuhan Yang Maha Esa lagi Maha Pengampun.

i. Mengucapkan dan membalas salam.

Salam bukan sekedar ungkapan kasih sayang tetapi, juga merupakan wujud pengharapan agar orang yang menerima maupun menjawab salam akan senantiasa berada dalam lindungan Allah SWT dan menjalani hidup yang penuh dengan kebaikan. Hal inilah yang membuat saling mengucapkan dan membalas salam penting untuk diterapkan dalam pembelajaran. Mengucap salam juga menjadi penawar penyakit hati seperti sombong dan keras hati yang tertunya merupakan sikap yang harus dihindari dalam proses pembelajaran.

\section{Setelah Pembelajaran}

a. Menyediakan waktu belajar ilmu agama sesuai dengan keyakinan masing-masing

Menurut Pancasila Sila Pertama, agama merupakan landasan dasar dalam kehidupan bermasyarakat dan bernegara. Setiap orang harus memiliki agama dan menjadikannya pedoman dalam menjalani kehidupan. Pedoman tersebut tentunya harus dipelajari dan dipahami dengan sebenar-sebenarnya agar pengaplikasiannya dalam kehidupan pun dapat maksimal dan sempurna. Oleh karena itu, guru dan siswa Indonesia yang beragama hendaknya menyediakan waktu untuk mempelajari agama yang dianut sebagai pedoman dalam menjalani kehidupan.

b. Mencari guru agama yang berkualitas

Guru agama yang berkualitas adalah seorang guru yang ahli dalam bidangnya. Guru agama (Islam) seperti ini menguasai ilmu tauhid/ketuhanan, ilmu fiqih/syariat, dan ilmu tasawuf/akhlak serta mampu mengajarkan nya dengan baik kepada murid- 
muridnya. Di samping itu, guru seperti ini tidak hanya ahli dalam teori tetapi dia dapat mengimplementasikan teori itu dalam kehidupan sehari-hari.

c. Merencanakan kegiatan belajar dengan berpedoman pada agama yang diyakini.

Merencanakan kegiatan belajar tidak hanya dilakukan guru, tetapi idealnya juga dilakukan oleh siswa. Dalam merencanakan kegiatan belajar, baik guru maupun siswa hendaknya merencanakan kegiatan belajar dengan berpedoman kepada agama dan keyakinan masing-masing.

d. Mendoakan satu sama lain di setiap kesempatan.

Setiap guru dan siswa hendaknya saling mendoakan di setiap kesempatan. Guru mendoakan siswa agar dimudahkan dalam memahami pelajaran yang diberikan. Sebaliknya, siswa mendoakan guru agar diberikan kemudahan dan kesabaran oleh Allah SWT dalam melaksanakan kegiatan pembelajaran.

Hal-hal yang disarankan di atas idealnya tidak bisa dilakukan oleh satu atau beberapa guru dan satu atau beberapa siswa saja. Hal-hal itu harus menjadi sebuah budaya yang berlaku di sebuah institusi pendidikan. Jika hal ini tidak dilakukan dengan segera dan bersama-sama maka hasil pembelajaran yang diharapkan tidak akan optimal.

\section{KESIMPULAN}

Guru harus memiliki pribadi yang dapat menjadi teladan bagi peserta didik. Keteladan hanya bisa ditimbulkan dengan melihat dan mencontoh pribadi-pribadi teladan. Salah satu contohnya adalah sosok 'muslimah': seorang pendidik yang berjuang tanpa pamrih dan mendedikasikan hidupnya untuk profesinya. Keteladanan ini perlu dilatih secara terus-menerus dimanapun dosen dan mahasiswa berada. Pada akhirnya, tulisan ini ditujukan pada diri penulis sendiri dan seluruh guru-guru Indonesia sebagai alat introspeksi diri terhadap apa-apa yang sudah, sedang, dan akan dilakukan bagi perbaikan dan peningkatan kualitas pembelajaran. Semoga apa yang dibahas dalam tulisan ini bermanfaat untuk pendidikan Indonesia yang lebih baik.

\section{DAFTAR PUSTAKA}

Adonara, Zahra. 2016. Lima Wejangan Bu Muslimah “Laskar Pelangi”, Untuk Para Guru Masa Kini (Online). (https://sangpencerah.id/), diakses pada 25 November 2019

Al-Mubarakfury, S.R. 2009. Sirah Muhammad: Sejak Sebelum Lahir Hingga Detik Terakhir Kehidupan Sang Nabi SAW. Jakarta: Abdika Press 
Asmani, Jamal Makmur. 2013. Tips Menjadi Guru Inspiratif, Kreatif, dan Inovatif. Yogyakarta: Diva Press

Golderg Mark F. 2003. The Qualities of Great Teachers. Marge Scherer (Ed). Keeping Good Teachers (224). Alexandria: ASCD Publications.

Harmer, Jeremy. 2007. The Practice of English Language Teaching ( $4^{\text {th }}$ ed.). Cambridge, Person Education

Jamaluddin. 2010. Guruku Tidak Kencisng Berlari. Banjarmasin: Tahura Media

Kementrian Pendidikan dan Kebudayaan Republik Indonesia Undang-Undang Guru dan Dosen Republik Indonesia Tahun 2005 tentang Kompetensi Profesional Guru (Online), (http://luk.staff.ugm.ac.id/), diakses pada 25 November 2019

Norlander-Case, Key A. dkk. 1999. Guru Profesional: Penyiapan dan Pembimbingan Praktisi Pemikir. Terjemahan Suci Romadhona. 2009. Jakarta: PT Macanan Jaya Cemerlang

Peraturan Menteri Pendidikan Nasional Republik Indonesia Nomor 16 Tahun 2007 tentang Standar Kualifikasi Akademik dan Kompetensi Guru (Online). (http://versalsp.data.kemdikbud.go,id), diakses pada 25 November 2019

Patil, Z.N. 2008. Rethinking The Objectives of Teaching English in Asia. In Asian EFL Journal. 10(4):227-232

Suyanto dan Jihad. Menjadi Guru Profesional: Strategi Meningkatkan Kualifikasi dan Kualitas Guru di Era Global. Jakarta: Penerbit Erlangga

Stronge, James H. 2002. Qualities of Effective Teachers. Alexandria: Association for Supervision and Curriculum Development

Undang-Undang Dasar 1945 (versi Amandemen) Pasal 31 ayat 3 dan 5 tentang Sistem Pendidikan Nasional. Penjelasan Pasal 31 UUD 1945. (https://www.limc4u.com), diakses 25 November 2019

Undang-Undang No. 14 Tahun 2005 Pasal 10 Ayat 1 tentang Guru dan Dosen (luk.staff.ugm.ac.id), diakses 25 November 2019

Undang-Undang No. 20 Tahun 2003 tentang Sistem Pendidikan Nasional. (https://kelembagaan.ristekdikti.go.id), diakses 25 November 2019 